EPIDEMIOLOGICAL REVIEW

\title{
Surveillance systems for STls in the European Union: facing a changing epidemiology
}

\author{
C M Lowndes, K A Fenton, the ESSTI (European Surveillance of STIs) Network*
}

Sex Transm Infect 2004;80:264-271. doi: 10.1136/sti.2004.010389

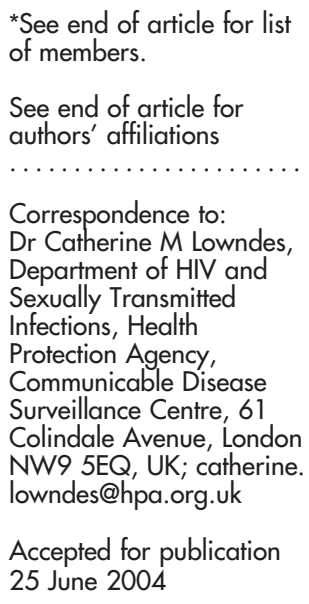

....................

\begin{abstract}
Objectives: To characterise the nature, content, and performance characteristics of existing national STI surveillance systems in the European Union (EU) and Norway, to facilitate collection of comparable surveillance data.

Methods: Cross sectional survey using a structured questionnaire.

Results: Case reporting from clinicians and/or laboratories is the mainstay of EU surveillance systems for bacterial STls. Coverage of case reporting varies from less than $10 \%$ to over $75 \%$, and lack of and/or heterogeneity in case definitions affect the relative specificity and sensitivity of reporting systems. Considerable variations also exist in STI care sites; the populations who use these services; and in partner notification practices, STI screening practices, and STI laboratory diagnostic tests employed, affecting the representativeness of reported data and the sensitivity of surveillance systems for detecting the true number of STI cases.

Conclusions: The heterogeneity of current surveillance systems complicates direct comparison of STI incidence rates across Europe. Introduction of standardised case definitions for reporting, and increased coverage of mandatory reporting systems where necessary, are needed. Definition of standardised minimum datasets and use of sentinel and enhanced surveillance systems to supplement universal case/ laboratory notification data, could improve our understanding of the distribution and determinants of STls across Europe, and aid in the design of effective public health responses. In the context of the changing epidemiology of STls, systems for detection and monitoring of localised outbreaks of acute bacterial STIs (syphilis and antimicrobial resistant gonorrhoea), as well as prevalence monitoring systems for frequently asymptomatic STIs (chlamydial infection and viral STIs), are also necessary.
\end{abstract}

$\mathrm{S}$ ince the mid-1990s, and after a decade and a half of declines, the European Union (EU) has experienced significant and sustained increases in the incidence of STIs. ${ }^{12}$ This is especially the case for the acute bacterial STIs gonorrhoea, syphilis, and genital chlamydial infection, where increases have been concentrated in young people, ethnic minorities, and men who have sex with men (MSM). These increases in STI incidence are occurring within a context of continuing transmission of HIV, with sexual transmission assuming increasing importance, and an increasing prevalence of HIV because of the success of highly active antiretroviral therapy. ${ }^{3}$

This changing epidemiology presents challenges to European countries, both in terms of understanding the distribution and determinants of STIs, as well as in terms of service provision and implementation of appropriate primary and secondary prevention measures.

Given that similar changes in STI epidemiology are occurring across the EU, and given the increasing fluidity of national borders both within and outside this region, there is a need for Europe-wide collaboration on STI surveillance, prevention, and control. ${ }^{4}$ This would enable comparison of disease rates and trends between countries, increase our understanding of the underlying factors driving STI transmission in Europe, and aid in the design and implementation of effective interventions.

The aim of this study was to characterise the nature, content, and performance characteristics of existing national STI surveillance systems in the EU, in order to facilitate the future collection of comparable surveillance data across Europe.

\section{METHODS}

This study was carried out as part of a European Commission funded project on European surveillance of STIs. A cross sectional survey of STI surveillance systems in 14 member states (that is, all except Luxembourg) and Norway (Norway is a member of the European Free Trade Association (EFTA) and the European Economic Area (EEA)) was carried out between November 2002 and July 2003, using a structured questionnaire.

The aim of the study was to gain a comprehensive understanding of current and planned STI surveillance systems, and to describe STI diagnostic, treatment, and care services, and STI prevention policies and practices, in participating countries. The survey questionnaire focused on the organisation of STI surveillance systems (including sources of information, STIs covered, case definitions, data collected, type and frequency of reporting, analysis and dissemination of surveillance data) and on their performance characteristics (data quality, case definitions, usefulness, sensitivity, representativeness, timeliness, and acceptability). ${ }^{5}$ It also included questions on the organisation of health care and systems for STI management; legislation concerning STI care; partner notification policies and practices; STI screening policies; STI outbreak detection and management; and health promotion and education. Respondents were also asked to

Abbreviations: DV, dermatovenereology; ESSTI, European Surveillance of Sexually Transmitted Infections; EU, European Union; GUM, genitourinary medicine; HPV, human papillomavirus; HSV, herpes simplex virus; IDUs, injecting drug users; MSM, men who have sex with men 
identify priorities for future surveillance developments, as well as current or planned changes to existing systems. The survey was confined to questions concerning national systems, policies, and actions. (A copy of the questionnaire is available from the corresponding author.)

STI surveillance leads in the 15 collaborating countries were sent a paper copy of the questionnaire, which, after completion, was returned by mail. Questionnaire data were analysed, summarised, and validated with survey participants. Additional material was provided by survey participants to supplement questionnaire data, including reporting forms, surveillance reports and data, published papers, and conference abstracts.

\section{RESULTS}

\section{STI care}

In the EU, healthcare and preventive services for STIs are provided through a variety of medical specialties and at a variety of clinical sites. Specialised confidential STI (genitourinary medicine (GUM) clinics in the United Kingdom: a network of free, open access STI clinics set up in 1913) or dermatovenereology (DV) services, or services within dermatology clinics (sometimes with dedicated hours for STI care), exist in most large towns and cities, where the majority of STI cases occur. Such services are frequently attached to hospitals as open access outpatient clinics, and STI care is usually free or largely free at the point of care. In Germany and Austria, open access (largely free) STI care is provided within local or municipal health offices, respectively, and in the Netherlands, free STI care is provided within municipal health services as well as at dedicated STI clinics. Anonymous HIV counselling and testing services are also frequently available at these centres.

Countries where the majority of bacterial and viral STI cases are seen at specialised STI/DV services include Ireland, Italy, and the United Kingdom, and this is the case in Sweden for gonorrhoea and syphilis cases, and in Denmark for syphilis cases. In general, higher proportions of gonorrhoea and syphilis cases than genital chlamydial infections and viral STIs are seen at dedicated STI/DV services. This reflects a tendency for the clientele at dedicated STI services to be from high risk, socially disadvantaged groups. Indeed, in some countries (including Ireland, the Netherlands, Portugal, and the United Kingdom), there is specific provision of STI services (or dedicated clinic opening times) for high risk, vulnerable and socially/economically marginalised populations, including men who have sex with men (MSM), injecting drug users (IDUs), illegal immigrants, and sex workers. Free monthly STI/HIV screening of registered sex workers is carried out in Austria and Greece.

Increases in the number of clients at STI/DV services have occurred in a number of countries, including Germany, Sweden, the United Kingdom, and Ireland, in recent years. This has led in some cases to changes from walk-in to appointment based services, as well as to increased waiting times for services.

Primary care services (general practitioners, family planning clinics, youth clinics, etc) manage considerable proportions of STI cases, particularly chlamydial infections and viral STIs, and particularly in Belgium, Finland, France, the Netherlands, Norway, Spain, and Sweden. Gynaecologists, both public and private, see considerable numbers of chlamydia and viral STI cases in countries other than Norway, Sweden, and the United Kingdom. Other sites where STIs are managed include infectious disease clinics (including HIV treatment services) and urology clinics. The private sector is important in STI care provision in many countries.
National guidelines for STI case management (diagnosis and treatment) exist in 11 out of 15 countries. Where information is available, these guidelines are in general used more frequently at specialised STI care sites (STI clinics, dermatovenereology clinics, dermatology clinics), than in other sites where STIs are seen.

\section{STI surveillance: case and laboratory reporting mechanisms \\ Mandatory STI case reporting}

The mainstay of European STI surveillance systems for acute bacterial STIs is case reporting from clinicians and/or laboratories. Universal physician case reporting is mandatory for gonorrhoea in $11 / 15$, and for syphilis in $12 / 15$, countries surveyed, and is mandatory from STI (GUM) clinics only in the United Kingdom (tables 1-3). In contrast, chlamydial infection is notifiable by clinicians only in Sweden, Ireland, and the United Kingdom (from GUM clinics only), with laboratory reporting or sentinel case reporting being more often relied upon for surveillance of this STI (tables 1-4).

Reporting frequencies for mandatory notifications (to district/regional or central levels, depending on the country) vary between daily and quarterly, while the time delay between a case being diagnosed and this information reaching the National Surveillance Centre varies from less than 1 month to up to 2 years (table 1 ).

Laboratory confirmation is required for reporting a case of syphilis in nine of the 13 countries where it is notifiable, and for reporting a case of gonorrhoea in seven of the 12 countries where it is notifiable (table 1). In Austria, Denmark, and Ireland, although not formally required, the majority of reported gonorrhoea cases are laboratory confirmed.

The amount and quality of data reported through mandatory case reporting systems vary widely, from only aggregate numbers of cases by region in Spain, to quite detailed sociodemographic and behavioural data in the Scandinavian countries (Sweden, Norway, and Denmark) and for gonorrhoea in Greece and syphilis in Germany (table 1). Coverage (the proportion of diagnosed STI cases actually reported to central level) of these systems also varies widely (table 1). In the United Kingdom and Ireland, coverage of STI clinic based reporting is estimated at over $75 \%$, as is coverage in the Scandinavian countries and Finland from all sites where STIs are seen, including from private physicians (table 1). Comparison of numbers of clinical and laboratory reports received by the Statens Serum Institute in Denmark indicates that approximately $45 \%$ and $35 \%$ of laboratory reported gonorrhoea and syphilis cases, respectively, are reported by clinicians. ${ }^{67}$ In Portugal (the result in part of the nominal nature of case reporting), Spain, and Italy, ${ }^{8}$ rates of under-reporting are high (less than $50 \%$ of diagnosed cases reported).

Given the diffuse nature of STI care sites, the representativeness of reporting systems is also a key factor determining their performance. For example, an Italian evaluation demonstrated marked geographical variations in notification rates, ${ }^{8}$ while in several other countries reporting rates from sites other than dedicated STI clinic sites, including primary care, are lower (table 1). In the United Kingdom, STIs are notifiable only from STI (GUM) clinics. Lack of reporting from private practitioners is also problematic in many countries.

Mandatory clinical reporting of viral STIs (genital herpes and warts) is compulsory only from STI clinics in the United Kingdom and Ireland, as is reporting of other STIs and STI syndromes (table 1). Congenital syphilis is notifiable in all countries surveyed except France and the Netherlands, and from STI clinics in the United Kingdom. 
Table 1 Mandatory STI case reporting systems in the European Union and Norway

\begin{tabular}{|c|c|c|c|c|c|c|c|c|c|c|}
\hline & \multirow{2}{*}{$\begin{array}{l}\text { Year } \\
\text { introduced }\end{array}$} & \multirow{2}{*}{$\begin{array}{l}\text { Notifiable } \\
\text { STIs }\end{array}$} & \multirow{2}{*}{$\begin{array}{l}\text { Laboratory } \\
\text { confirmation } \\
\text { required }\end{array}$} & \multicolumn{3}{|l|}{ Coverage } & \multirow{2}{*}{$\begin{array}{l}\text { Individual/ } \\
\text { aggregate } \\
\text { (I/A) }\end{array}$} & \multirow{2}{*}{$\begin{array}{l}\text { Variables } \\
\text { reported }\end{array}$} & \multirow{2}{*}{$\begin{array}{l}\text { Reporting } \\
\text { frequency }\end{array}$} & \multirow{2}{*}{$\begin{array}{l}\text { Time delay } \\
\text { to NSC }\end{array}$} \\
\hline & & & & Syphilis & Gonorrhoea & Chlamydia & & & & \\
\hline Austria & 1945 & Syph; Gc* & No & $51-75 \%$ & Low & NA & $A$ & $D, G$ & Monthly & $<1$ month \\
\hline Belgium & 1945 & Syph; Gc* & No & Low & Very low & NA & & $A, D, G, P, R$ & Daily & \\
\hline Denmark & 1865 & Syph; Gc & Syph & $26-50 \% \dagger$ & $26-50 \% \dagger$ & NA & I & $\begin{array}{l}\text { A, B, C, D, G, H, } \\
\text { I, P, RF, S, T, X }\end{array}$ & Daily & Variable \\
\hline Finland & 1939 & Syph; Gc & Syph; Gc & $76-99 \% \ddagger$ & 76-99\%‡ & NA & I & $\begin{array}{l}A, B, C, D, G \\
I, P, R, S\end{array}$ & Weekly & $<1$ month \\
\hline France & NA & None & NA & NA & NA & NA & NA & NA & NA & NA \\
\hline Germany & 2001 & Syph & Syph & $76-99 \%$ & NA & NA & 1 & $\begin{array}{l}\text { A, B, D, G, I, } \\
P, R F, T\end{array}$ & Daily & $<1$ month \\
\hline Greece & 1950 & Syph; Gc & Syph; Gc & NK & $51-75 \% \dagger$ & NA & I & $\begin{array}{l}\text { A, C, G, R } \\
\text { (syphilis); A, B, C, } \\
\text { D, G, H, I, O, P, } \\
\text { R, RF, S, T, X (Gc) }\end{array}$ & $\begin{array}{l}\text { Weekly (G) } \\
\text { Monthly (S) }\end{array}$ & 1 week (Gc) \\
\hline $\begin{array}{l}\text { Republic of } \\
\text { Ireland }\end{array}$ & 1981 & $\begin{array}{l}\text { Syph; Gc; } \\
\mathrm{Ct}^{\star} \S\end{array}$ & No & 76-99\%† & 76-99\%† & $76-99 \% \dagger$ & $A$ & $A, C, G$ & Quarterly & $\begin{array}{l}\text { Mean } \\
1 \text { year }\end{array}$ \\
\hline Italy & 1956 & Syph; Gc & Syph; Gc & $26-50 \%$ & $26-50 \%$ & NA & I & $A, B, G, R$ & Monthly & $1-2$ years \\
\hline Netherlands & 1976-98 & None & NA & NA & NA & NA & NA & NA & NA & NA \\
\hline Norway & 1922 & Syph; Gc* & Syph; Gc & 76-99\% & 76-99\%‡ & NA & 1 & $\begin{array}{l}\text { A, B, C, D, G, H, I, } \\
O, P, R, R F, S, T, X\end{array}$ & Daily & $<1$ month \\
\hline Portugal & 1950 & Syph; Gc & $\begin{array}{l}\text { Syph; Gc } \\
1999\end{array}$ & Low & Very low & NA & I & $A, D, G, R, T$ & Daily & $\begin{array}{l}1 \text { week- } \\
1 \text { year }\end{array}$ \\
\hline Spain & 1982 & Syph; Gc & $\mathrm{No}^{* *}$ & Low & Very low & NA & A & $\mathrm{N}$ & & \\
\hline Sweden & $\begin{array}{l}1912 \\
1988\end{array}$ & $\begin{array}{l}\text { Syph; Gc; } \\
\mathrm{C}^{*}\end{array}$ & Syph; Gc; Ct & 76-99\%‡ & 76-99\%‡ & 76-99\%‡ & 1 & $\begin{array}{l}\text { A, C, D, G, I, P, } \\
R, R F, S, T, X\end{array}$ & Daily & $<1$ month \\
\hline UK & 1916 & $\begin{array}{l}\text { Syph; Gc; } \\
\mathrm{C}+\star \S^{\star} \S\end{array}$ & Syph; Gc; Ct & 76-99\%† & 76-99\%† & 76-99\%† & Att & $A, D, G, O, P$ & Quarterly & $3-6$ months \\
\hline
\end{tabular}

Ct, Chlamydia trachomatis; Gc, gonorrhoea; Syph, syphilis; NK, not known; NSC, National Surveillance Centre; NA, not applicable (system not in operation in that country).

A, age; $B$, nationality/country of birth; $C$, clinic type; D, date of diagnosis; $G$, gender; $H, H I V$ status; I, country where infection contracted; $N$, number of cases by region only; $\mathrm{O}$, male sexual orientation; $\mathrm{P}$, place of diagnosis; $\mathrm{R}$, place of residence; $\mathrm{S}$, site of infection; $\mathrm{T}$, probable route of transmission; $\mathrm{X}$, reason for testing; $\mathrm{RF}$, other risk factor variables of relevance to STI transmission (eg, number of partners; history of STI; drug use; contact with sex worker; gender of sex partner; linked cases; etc).

*Mandatory reporting also for rare bacterial STIs (lymphogranuloma venereum, granuloma inguinale (donovanosis), and chancroid). In Norway, mandatory reporting of rare bacterial STIs was discontinued from July 2003. In Sweden, chancroid will be removed from the list of notifiable diseases when the new Infectious Disease Control Act comes into force in July 2004. In Austria, a case is reportable by law only if spread of the infection is possible, or if the infected person is unwilling to undergo treatment.

†Denmark, Ireland, Greece, and UK: coverage given is for reporting from STI clinics only. In Ireland and Greece, although case notification for syphilis, gonorrhoea, and chlamydia is universally mandatory, in practice generally only STI clinics report (in Greece, only the two largest STI/DV clinics, situated in Athens and Thessaloniki, report data). In the UK, reporting is mandatory only from STI (GUM) clinics. In Denmark, comparison of laboratory and clinical reports indicates that under-reporting from clinicians is greater outside dedicated public STI clinic settings-for example, while approximately $65 \%$ of clinical notifications of gonorrhoea come from STI clinics, $60 \%$ of positive laboratory test results are from specimens taken by GPs.

flncluding from private physicians.

§UK and Ireland: also genital herpes, ano-genital warts, trichomoniasis, chancroid, lymphogranuloma venereum, donovanosis (granuloma inguinale), molluscum contagiosum, hepatitis B, non-specific urethritis, candidiasis, Pediculosis pubis, and PID in the UK only. In Ireland, candidiasis, molluscum contagiosum and Pediculosis pubis will be removed from the list of notifiable diseases when new legislation comes into force in late 2003. Compulsory universal laboratory reporting of STls is also being introduced as part of the new legislation.

- In Portugal, a new mandatory reporting system with case definitions for reporting (including laboratory confirmation of cases of syphilis and gonorrhoea) and an expanded dataset was introduced in 1999. However, in practice it appears that variable fields are rarely completed and case definitions for reporting have not been adopted.

${ }^{* *}$ In Spain, new case definitions for reporting, including requirements for laboratory confirmation, will be introduced shortly.

t†ln the UK, an individual, patient based reporting (ProgrESS) system with an expanded dataset has been piloted in London and will be phased in throughout the UK over the next 2 years. Patient based reporting is already in place in Scotland.

\section{Laboratory reporting}

Eight out of 15 countries have systems for mandatory or voluntary universal reporting of STI diagnostic test results from laboratories (table 2). In Belgium, France, the Netherlands and Spain, voluntary sentinel (sample based) laboratory reporting systems exist (table 3). Laboratory data are not currently reported for surveillance purposes in Italy, Ireland, or Portugal. However, compulsory universal laboratory reporting for STIs will be introduced in Portugal and Spain within the next few years. In Ireland, a national computerised infectious disease reporting system, with one national data repository, to collate, analyse, and disseminate laboratory based information and clinical notification data, will be introduced in 2004 .

Electronic reporting is more common for laboratory than for clinical notifications, as is aggregate reporting (table 4). Denominator data are reported in Denmark, Norway, and Sweden (and in Greece for Neisseria gonorrhoeae). In Denmark ${ }^{9}$ and Finland, the type of diagnostic test used for detection of chlamydia is also reported. Timeliness tends to be better for laboratory than for case reporting, the result in part of the more common automated, electronic nature of reporting (table 4).

Coverage of universal laboratory reporting systems in the Scandinavian countries and Finland is estimated at over $75 \%$ (table 4), and at close to $100 \%$ in Sweden, including from private laboratories. In the United Kingdom, coverage is lower, particularly in London where a significant proportion of STI cases diagnosed in the United Kingdom are seen. ${ }^{10}$ The sentinel laboratory reporting systems in Spain, France and the Netherlands are estimated to cover between $10-25 \%$ of diagnosed cases (table 3).

\section{Surveillance of $N$ gonorrhoeae antimicrobial susceptibility}

National surveillance (either sentinel or universal) of gonococcal antimicrobial resistance is carried out in 
Table 2 Laboratory reporting systems in the European Union and Norway-universal laboratory reporting systems

\begin{tabular}{|c|c|c|c|c|c|c|c|c|c|}
\hline & \multirow{2}{*}{$\begin{array}{l}\text { Year } \\
\text { introduced }\end{array}$} & \multirow[b]{2}{*}{ STIs reported* } & \multicolumn{3}{|l|}{ Coverage } & \multirow{2}{*}{$\begin{array}{l}\text { Individual/ } \\
\text { aggregate } \\
\text { reporting } \\
\text { (I/A) }\end{array}$} & \multirow{2}{*}{$\begin{array}{l}\text { Variables } \\
\text { reported }\end{array}$} & \multirow{2}{*}{$\begin{array}{l}\text { Reporting } \\
\text { frequency }\end{array}$} & \multirow{2}{*}{$\begin{array}{l}\text { Denominator } \\
\text { data** }^{* *}\end{array}$} \\
\hline & & & Syphilis & Gonorrhoea & Chlamydia & & & & \\
\hline Austria & & Syph; Gc (V) & $51-75 \%$ & $51-75 \%$ & NA & $A$ & $G$ & Monthly & No \\
\hline Denmark & 1994 & $\begin{array}{l}\text { Gc; Ct (M) } \\
\text { Syph (V) }\end{array}$ & $76-99 \% \dagger$ & 76-99\%† & $76-99 \% \dagger$ & $\begin{array}{l}\text { Gc, Ct: I } \\
\text { Syph: A }\end{array}$ & $A, C, D, G, L, S$ & $\begin{array}{l}\text { G: continuous } \\
\text { C: quarterly }\end{array}$ & $\mathrm{Gc} ; \mathrm{Ct}$ \\
\hline Finland & 1995 & Syph; Gc; Ct (M) & 76-99\% & 76-99\% & 76-99\%‡ & I & $A, D, G, L, P, S$ & Weekly & No \\
\hline Germany & 2001 & Syph (M) & $76-99 \%$ & NA & NA & i & व & & No \\
\hline Greece & 1987 & Syph; Gc (M) & NK & $51-75 \%$ & NA & Syph: A Gc: I & Syph: N; Gc: & Weekly & Gc \\
\hline Netherlands & & $\mathrm{Ct}$; herpes & NA & NA & & & & Monthly & \\
\hline Norway & $\begin{array}{l}1975 \text { (Syph; } \\
\text { Gc); } 1986 \text { (Ct) }\end{array}$ & $\begin{array}{l}\text { Syph; Gc; Ct } \\
\text { (M) }\end{array}$ & $76-99 \% \ddagger$ & 76-99\%‡ & 76-99\%‡ & $\begin{array}{l}\text { Ct: A } \\
\text { Syph, Gc: I }\end{array}$ & - & $\begin{array}{l}\text { Syph and Gc: } \\
\text { weekly; Ct yearly }\end{array}$ & $\mathrm{Gc} ; \mathrm{Ct}_{\mathrm{t}}$ \\
\hline Sweden & $\begin{array}{l}\text { Gc: NK Ct: } \\
1983\end{array}$ & $\mathrm{Gc} ; \mathrm{Ct}(\mathrm{V})$ & NA & 76-99\%‡ & $76-99 \% \ddagger$ & A & $A, G$ & 6 monthly & $\mathrm{Gc}, \mathrm{Ct}$ \\
\hline UK & & $\begin{array}{l}\text { Syph; Gc; Ct; } \\
\text { herpes (V) }\end{array}$ & $26-50 \%$ & $51-75 \%$ & $51-75 \%$ & I & $A, D, G, P, S$ & & No \\
\hline \multicolumn{10}{|c|}{$\begin{array}{l}\text { Ct, Chlamydia trachomatis; Gc, gonorrhoea; Gc AMR, gonococcal antimicrobial resistance; H, genital herpes; NSC, National Surveillance Centre; Syph, syphilis } \\
\text { NA, not applicable: system not in operation in that country. A, age; C, clinic type; D, date of diagnosis; G, gender; I, country where infection contracted; L, type o } \\
\text { laboratory test used; N, number of positive results only, by region; P, place of diagnosis; S, specimen type/site of infection. } \\
\text { *Mandatory (M) or voluntary (V). } \\
\text { **Negative results/total no of tests) reported. } \\
\text { †Denmark: coverage rates for chlamydia and gonorrhoea reporting (unknown for syphilis). Private laboratories do not carry out testing for chlamydia and } \\
\text { gonorrhoea in Denmark. Reporting frequency for Gc: was quarterly, but now most laboratories report Gc continuously (reporting forms submitted with isolates) } \\
\text { tlncluding from private laboratories. } \\
\text { - Linkage of individual clinical case and laboratory reports at the National Surveillance Centre. }\end{array}$} \\
\hline
\end{tabular}

Belgium, Denmark, Finland, France, Greece, Norway, and the United Kingdom (table 4). While some other countries carry out susceptibility testing of gonococcal isolates, data are used for clinical purposes only (or are analysed at regional rather than central level as in Sweden), and are not reported to national surveillance centres/ministries of health for surveillance purposes.

\section{Sentinel surveillance systems}

Seven EU countries have voluntary sentinel STI case reporting systems in operation, the majority of which have been introduced recently (table 4). Data on a larger number of STIs, including viral STIs, and on STI syndromes (urethritis, PID, cervicitis), are usually collected through these systems than through mandatory universal systems, as well as more and better quality sociodemographic, clinical, and sexual behaviour data (table 4). In Finland ${ }^{11}$ and Germany, both clinician and patient filled forms are employed.

Clinic types participating in these systems vary from public STI/DV clinics only (Italy ${ }^{12}{ }^{13}$ and Portugal ${ }^{14}$ ), to systems which sample a variety of sites where STIs are seen, including primary care and private physicians (table 4). In Spain, a sentinel network of 10 STI clinics, which currently participate in HIV prevalence monitoring, is being established. In Germany, Finland,${ }^{11}$ and Belgium, ${ }^{15}$ a variety of sites chosen to be representative of all clinical settings where STIs are managed, including STI clinics, gynaecology, urology, dermatology and HIV treatment clinics, general practitioners, family planning, youth and university clinics, are included. In some cases sites have also been chosen to be geographically representative and/or to include specific risk groups under surveillance. As discussed above, sentinel laboratory reporting systems are also in place in Belgium, France, the Netherlands, and Spain (table 3).

In France, a number of different sentinel surveillance systems exist, including urethritis reporting from $\mathrm{GPs}^{16}$ using a web based data entry system and sentinel laboratory reporting of gonorrhoea and chlamydia, as well as ad hoc collection of data on gonorrhoea cases seen at public STI (DAV, dispensaires antiveneriens) clinics. Data from these different systems have been used to triangulate and validate

Table 3 Laboratory reporting systems in the European Union-sentinel (sample based) laboratory reporting systems

\begin{tabular}{|c|c|c|c|c|c|c|c|}
\hline & $\begin{array}{l}\text { Year } \\
\text { introduced }\end{array}$ & STls & Sample & Variables reported & Reporting frequency & $\begin{array}{l}\text { Negative results } \\
\text { reported }\end{array}$ & Coverage \\
\hline Belgium & 1986 & $\mathrm{Gc}, \mathrm{Ct}$ & $\begin{array}{l}129 \text { laboratories } \\
\text { (public and private) }\end{array}$ & Individual A, G, L, S & Daily or weekly & No & $\begin{array}{l}\text { About half the } \\
\text { laboratories in } \\
\text { Belgium take part in } \\
\text { the sentinel system }\end{array}$ \\
\hline $\begin{array}{l}\text { France } \\
\text { RENAGO } \\
\text { RENACHLA }\end{array}$ & 1986 & $\begin{array}{l}\text { Gc, Ct, } \\
\text { GC AMR }\end{array}$ & $\begin{array}{l}\text { Public and private labs } \\
\text { geographically } \\
\text { representative sample }\end{array}$ & $\begin{array}{l}\text { Individual A, C, D, } \\
G, I, L, P, S\end{array}$ & Monthly & $\begin{array}{l}\text { Yes (aggregate: } \\
\text { total number tests } \\
\text { performed each } \\
\text { month) }\end{array}$ & $\begin{array}{l}5 \% \text { of all labs; } \\
10-25 \% \text { of } G \text { \& C } \\
\text { cases in country }\end{array}$ \\
\hline $\begin{array}{l}\text { Netherlands } \\
\text { ISIS }\end{array}$ & 1999 & $\begin{array}{l}\text { Syphilis, } \\
\text { Gc, Ct }\end{array}$ & $\begin{array}{l}\text { Convenience sample } \\
\text { of labs, ongoing } \\
\text { progressive recruitment }\end{array}$ & $\begin{array}{l}\text { Individual } A, C, D \text {, } \\
G, L, P, S\end{array}$ & $\begin{array}{l}\text { Daily to RIVM } \\
\text { (automatic electronic } \\
\text { upload overnight) }\end{array}$ & Yes & $\begin{array}{l}\text { Covers about } 3 / 16 \\
\text { million population }\end{array}$ \\
\hline $\begin{array}{l}\text { Spain } \\
\text { SIM }\end{array}$ & 1989 & $\begin{array}{l}\text { Syphilis, Gc, } \\
\text { Ct, Herpes }\end{array}$ & 44 laboratories & $\begin{array}{l}\text { Aggregate: no. positive } \\
\text { diagnoses by sex }\end{array}$ & $\begin{array}{l}\text { Time delay to ISCIII } \\
\sim 1 \text { month }\end{array}$ & No & $\begin{array}{l}\text { Covers } \sim 25 \% \text { of } \\
\text { population }\end{array}$ \\
\hline
\end{tabular}

Ct, Chlamydia trachomatis; Gc, gonorrhoea; Gc AMR, gonococcal antimicrobial resistance; H, genital herpes; NSC, National Surveillance Centre; Syph, syphilis; NA, not applicable: system not in operation in that country. A, age; C, clinic type; D, date of diagnosis; $G$, gender; I, country where infection contracted; L, type of laboratory test used; $\mathrm{N}$, number of positive results only, by region; $\mathrm{P}$, place of diagnosis; $\mathrm{S}$, specimen type/site of infection. 
Table 4 Summary of STI surveillance systems in operation in the European Union and Norway

\begin{tabular}{|c|c|c|c|c|c|c|c|c|}
\hline & \multirow{2}{*}{$\begin{array}{l}\text { Mandatory } \\
\text { universal case } \\
\text { reporting } \\
\text { of major } \\
\text { bacterial STls } \\
\text { (Syph, Gc, Ct) }\end{array}$} & \multicolumn{3}{|c|}{ Sentinel case reporting } & \multirow[b]{2}{*}{$\begin{array}{l}\text { Universal } \\
\text { laboratory } \\
\text { reporting }\end{array}$} & \multirow[b]{2}{*}{$\begin{array}{l}\text { Sentinel } \\
\text { laboratory } \\
\text { reporting }\end{array}$} & \multirow{2}{*}{$\begin{array}{l}\text { Enhanced } \\
\text { surveillance } \\
\text { systems for } \\
\text { syphilis }\end{array}$} & \multirow{2}{*}{$\begin{array}{l}\text { National } \\
\text { gonococcal } \\
\text { antimicrobial } \\
\text { resistance } \\
\text { surveillance } \\
\text { systems }\end{array}$} \\
\hline & & $\begin{array}{l}\text { Year } \\
\text { introduced }\end{array}$ & $\begin{array}{l}\text { STls/syndromes } \\
\text { reported }\end{array}$ & Reporting sites & & & & \\
\hline Austria & Syph, Gc & & Syph; Gc; Ct & STI and DV clinics & & Syph, Gc, Ct & NA & $\begin{array}{l}\text { Sentinel (STI } \\
\text { centre and } \\
\text { some DV clinics) }\end{array}$ \\
\hline Belgium & Syph, Gc & 2000 & $\mathrm{Ce}, \mathrm{P}, \mathrm{U}, \mathrm{X}$ & Various* & NA & Syph, Gc, Ct & NA & All isolates \\
\hline Denmark & Syph, Gc & NA & NA & NA & Syph, Gc, Ct & NA & NA & All isolates \\
\hline Finland & Syph, Gc & 1995 & $x$ & Varioust & Syph, Gc, Ctł & NA & NA & $\begin{array}{l}\text { Sentinel (FiRe } \\
\text { network) }\end{array}$ \\
\hline France & NA & 1986 & U§ & GPs§ & NA & $\mathrm{Gc}, \mathrm{Ct}$ & $\begin{array}{l}\text { Sample of STI } \\
\text { clinics }\end{array}$ & $\begin{array}{l}\text { Sentinel (linked } \\
\text { to RENAGO) }\end{array}$ \\
\hline Germany & Syph & 2003 & $\mathrm{Ce}, \mathrm{P}, \mathrm{U}, \mathrm{X}$ & Various ${ }^{* *}$ & Syph $\ddagger$ & NA & NA & Planned \\
\hline Greece & Syph, Gc & NA & NA & NA & Syph, Gcł & NA & NA & $\begin{array}{l}\text { All isolates from } \\
\text { two largest STI } \\
\text { clinics }\end{array}$ \\
\hline Ireland & Syph, Gc, Ct & NA & NA & NA & NA & NA & $\begin{array}{l}\text { All sites where } \\
\text { cases seen }\end{array}$ & NA \\
\hline Italy & Syph, Gc & 1991 & $P, U, X$ & STI clinics & NA & NA & NA & NA \\
\hline Netherlands & NA & 2003 (SOAP) & $P, U, X$ & STI and MHS clinics & NA & Syph, Gc, Ct & NA & NA \\
\hline Norway & Syph, Gc & NA & NA & NA & Syph, Gc‡ Ct & NA & NA & All isolates \\
\hline Portugal & Syph, Gc & 2003 & $\mathrm{Ce}, \mathrm{P}, \mathrm{U}, \mathrm{X}$ & DV clinics & NA & NA & NA & $\begin{array}{l}\text { Isolates from STI } \\
\text { clinic in Lisboa }\end{array}$ \\
\hline $\begin{array}{l}\text { Spain } \\
\text { SIM }\end{array}$ & Syph, Gc & $\begin{array}{l}\text { Under } \\
\text { construction }\end{array}$ & & STI clinics & NA & $\begin{array}{l}\text { Syph, Gc, } \\
\text { Ct, H }\end{array}$ & NA & NA \\
\hline Sweden & Syph, Gc, Ct & NA & NA & NA & $\mathrm{Gc}, \mathrm{Ct}$ & NA & NA & NA \\
\hline UK & $\begin{array}{l}\text { Syph, Gc, Ct } \\
\text { STI clinics only }\end{array}$ & NA & NA & NA & $\begin{array}{l}\text { Syph, Gc, } \\
\mathrm{Ct}, \mathrm{H}\end{array}$ & NA & All STI clinics & $\begin{array}{l}\text { Sentinel: } \\
\text { selected STI } \\
\text { clinics, June-- } \\
\text { August†† }\end{array}$ \\
\hline
\end{tabular}

NA, not applicable: system not in operation in that country; NSC, National Surveillance Centre; Syph, syphilis; Gc, gonorrhoea; Ct, Chlamydia trachomatis; H, genital herpes; P, HPV (human papillomavirus); $X$, syphilis, gonorrhoea, chlamydia, genital herpes, genital warts; U, urethritis; $P$, pelvic inflammatory disease; Ce, cervicitis; MHS, municipal health services.

*Belgium: sentinel case surveillance system: GPs; STI, dermatovenereology, gynaecology, and urology clinics; student clinics and sexual education centres. There are 29 sites in total (sites must have a minimum of 10 cases/year/site); reporting between October and January every year.

†Finland: sentinel case surveillance system: STI, gynaecology and student clinics; primary healthcare centres (family planning, GP, youth). Coverage: 10-25\% of chlamydia and syphilis cases; $26-50 \%$ of gonorrhoea cases diagnosed in the country (cf, KTL universal reporting figures).

flinkage of individual clinical case and laboratory reports at the National Surveillance Centre.

§France: Sentinel web based urethritis reporting system, about 500 out of 50000 GPs (survey: $<10 \%$ of urethritis cases in country reported through this system; the case definition for urethritis is recent pain on urination or urethral discharge), run by INSERM since 1986 (Reseau Sentinelles). Monthly aggregate reporting from INSERM to InVS

- France: sentinel enhanced reporting system for syphilis in 20 of largest cities in France: STI (DAV) clinics; some private physicians; internal medicine clinics in hospitals. A sentinel clinical reporting system for gonorrhoea is also planned, from the same cities and sites as the current syphilis sentinel reporting system.

${ }^{* *}$ Germany: local health offices, hospital based STI clinics, private gynaecologists, dermatologists, urologists, and HIV specialists.

t†ln Scotland, all isolates are tested at the National Reference Laboratory.

STI trends over time, ${ }^{17}$ and to estimate gonorrhoea incidence in men and women in France in $1990 .^{18}$

\section{Enhanced surveillance systems and syphilis outbreak} surveillance

Survey respondents reported that localised outbreaks (linked in terms of time, place, and person) of syphilis have occurred over the last 5 years in at least 11 of the 15 European countries surveyed. In the Scandinavian countries, Finland and Germany, fairly comprehensive data on syphilis cases are collected through mandatory universal reporting systems. Other countries, including the United Kingdom, France, and Ireland, ${ }^{19}$ have recently implemented enhanced surveillance systems for laboratory confirmed cases of syphilis (table 4). In France, this is a sentinel system, involving STI (DAV) clinics in the 20 largest cities in France, as well as internal medicine clinics in some hospitals. These systems collect expanded behavioural and sociodemographic data sets relevant to epidemiology, service provision, and design of preventive interventions. In Belgium, a recent ad hoc study of laboratory syphilis reports highlighted the increased incidence of syphilis, and plans are under way to include syphilis in the sentinel laboratory reporting system in the near future. ${ }^{20}$ Outbreaks of gonorrhoea and antimicrobial resistant gonorrhoea have also been relatively common. ${ }^{2}$

\section{Planned developments and priorities for} improvements to surveillance systems

A number of common priorities for developments of and improvements to STI surveillance systems, where necessary, were identified by survey respondents including increasing the coverage and timeliness of universal case reporting systems; introducing disaggregate data collection; improvements in the amount and quality of data reported; implementation of sentinel and enhanced surveillance systems; and introduction or expansion of laboratory reporting systems. Norway, Sweden, and the Netherlands are planning to introduce automated "flagging" mechanisms in central databases in order to detect localised increases in numbers of reported STI cases (outbreaks).

\section{Additional factors affecting the sensitivity of STI surveillance systems: secondary STI prevention practices}

The sensitivity (that is, the proportion of all STI cases occurring which are detected) of STI surveillance systems 
depends not only on the coverage (that is, the proportion of all cases diagnosed which are reported) of the system, but also on the proportion of cases occurring that are diagnosed. This is particularly so for frequently asymptomatic STIs such as chlamydial infection. Two major factors impacting the proportion of STI cases detected are screening and contact tracing practices.

Screening practices for STIs vary widely across European countries. STI clinic attendees and pregnant women are the population groups most frequently screened, although the STIs for which they are screened, including chlamydial infection, vary. Syphilis serological screening is carried out in pregnant women in all countries except France, although in Denmark this is now selective rather than universal. Policies and practices for screening for chlamydial infection also vary widely, including within countries, from testing in some STI clinics only, through screening of pregnant women, to screening of attendees at primary care sites including general practitioners. In Sweden, screening is carried out in STI clinics and youth clinics. In the United Kingdom a national screening programme has recently been established, ${ }^{21}$ and studies are under way to inform future screening policy in some countries, including the Netherlands, ${ }^{22}$ Ireland, and Denmark. ${ }^{23}$ It is striking to note that in nearly all countries surveyed, even where STI screening programmes are in place, data from such programmes, including from syphilis screening programmes in pregnant women, are usually not reported or used for surveillance purposes.

Considerable variations also exist in partner notification practices for STIs in western European countries. ${ }^{24}$ Contact tracing is obligatory in Norway and Sweden, and voluntary in most other countries. Contact tracing is usually undertaken for bacterial STIs at specialised STI care sites (STI/DV clinics), and less frequently for genital warts and herpes. Patient referral is used for partner notification in all countries, while provider referral is also practised in the United Kingdom, Sweden, Finland, Norway, and Ireland. At specialised STI care sites, for countries where data are available, the estimated proportion of contacts reached varies between less than $10 \%$ and more than $75 \%{ }^{24}$ Apart from in Norway and Sweden, partner notification is carried out infrequently at non-specialised STI care sites in other countries, particularly in primary care settings.

\section{DISCUSSION}

Recent increases in STI incidence highlight the need for systems that effectively monitor STI trends and distribution in a timely and efficient manner, in order to inform public health action. The consistency of STI trends across Europe points to common causative factors, common priorities, and a need for shared solutions. ${ }^{2}$

Case reporting from clinicians and/or laboratories is the mainstay of European surveillance systems for syphilis, gonococcal, and chlamydial infections. Syphilis and gonorrhoea are compulsorily notifiable by clinicians in the majority of countries surveyed, while laboratory reporting is more frequently relied upon for surveillance of chlamydial infection. Considerable variation exists in the timeliness of reporting through these systems, the amount and quality of data reported, and their coverage, specificity, and representativeness. The relative sensitivity of systems for detecting the true population burden of STIs is affected by variations in types of laboratory diagnostic test used, and by STI screening and contact tracing practices. Differences in case definitions, notably the requirement for laboratory confirmation for reporting, affect the relative specificity of different systems. Variations in STI care sites and the populations who use STI services, and the important role of the private sector in STI care in some countries, ${ }^{25}{ }^{26}$ affect the representativeness of reporting systems, with, in some countries, geographical differences in coverage, ${ }^{8}$ as well as differential reporting rates from different sites where STIs are treated.

In some countries, mandatory universal STI case reporting has been discontinued, ${ }^{27}{ }^{28}$ while in others systems suffer from problems of coverage and representativeness, and/or a lack of sufficient reported data. In these countries, sentinel case reporting systems have been introduced or are under construction, and tend to produce more and better quality clinical, sociodemographic, and behavioural data. Mandatory or voluntary, universal or sentinel, laboratory reporting systems exist in the majority of the countries surveyed, and enhanced surveillance systems for syphilis have also been introduced in a number of countries, as have systems for monitoring of gonococcal antimicrobial resistance.

The present study confirms findings from previous studies indicating considerable variations in STI care and preventive services, as well as the heterogeneous nature and performance characteristics of STI surveillance systems in Europe. ${ }^{29-31}$ Nevertheless, the basic STI reporting modalities and mechanisms are similar across the EU and Norway. Furthermore, respondents identified several common areas for improvements to existing systems, including, where necessary, increasing the coverage and timeliness of universal case reporting systems; introducing disaggregate data collection; improvements in the amount and quality of data reported; implementation of sentinel and enhanced surveillance systems; introduction or expansion of laboratory reporting systems; and surveillance of gonococcal antimicrobial resistance.

Improving the coverage of basic universal case reporting is a priority for some European countries. One option is to obtain this information through laboratory reporting, where automated, electronic data transfer is particularly feasible, and where denominator and test type data reporting provide useful additional information, particularly for monitoring chlamydia screening and testing practices. Standardisation of case definitions for reporting, and increased coverage, would enable more accurate estimation of the minimum population burden of STIs, as well as more direct comparisons of STI incidence across Europe.

In the Scandinavian countries and Finland, absolute numbers of acute bacterial STIs are relatively small, and universal reporting systems with high coverage and good quality sociodemographic and behavioural data exist. With the exception of syphilis, however, numbers of other STI cases occurring in the larger European countries may make implementation of such universal systems impracticable, particularly with respect to primary care sites. ${ }^{25}$

Sentinel (sample based) systems are in general not useful for estimating STI incidence or the burden of STI in the population, since the denominator population from which cases are drawn cannot normally be defined, and thus the proportion of STI cases diagnosed in the country which the sample represents cannot be accurately determined. However, these systems are useful for following comparative trends in STI incidence and for understanding the factors driving STI transmission. They may also be useful for detection of changes in the incidence of particular STIs in specific risk groups, such as MSM. Such systems are in operation (or under construction) in the majority of larger European countries as well as in Austria, Belgium, and Finland. In order to be representative, it is important that the composition of sentinel sites reflects the distribution of STI care within different modalities in each country, including in the private sector.

Definition of standardised clinical, sociodemographic, and behavioural datasets for universal (where feasible) and (otherwise) sentinel reporting would facilitate comparison 
of surveillance data, and aid in the understanding and the comparison of the distribution of STIs and of the factors driving their transmission in different European countries.

For bacterial STIs such as syphilis and to some extent gonorrhoea, which tend to be confined to high risk groups and are largely symptomatic, traditional incident case reporting and case finding measures may be the best approach to detect and control these infections in the population. In addition, owing to the localised distribution of these STIs, surveillance systems must be able to detect localised changes in incidence in a timely fashion, and rapidly implement measures to both understand transmission dynamics and implement appropriate targeted responses. This has been achieved in a number of European countries in response to the recent syphilis outbreaks, either through timely universal reporting systems which provide sufficient information (for example, Sweden, Norway, and Germany), or through specific enhanced surveillance systems (for example, France, the United Kingdom, and Ireland). Such systems enable characterisation of the populations where transmission is occurring and the implementation of appropriate targeted, control measures. ${ }^{2}$ They may also be useful for detection of unusual outbreaks of other STIs in high risk groups, including hepatitis A, shigellosis and, more recently, lymphogranuloma venereum outbreaks among MSM. $^{32-37}$ Furthermore, given that gonococcal antimicrobial resistance is assuming increasing importance in Europe, surveillance is urgently required to rapidly detect changes in patterns of resistance which could impact on the treatment success of currently used drugs and the transmission of drug resistant strains. ${ }^{38-43}$

On the other hand, STIs which are largely asymptomatic, and which are more widely distributed in the population, pose special challenges to surveillance systems based on reporting of incident STI cases. ${ }^{44}$ This is particularly so for genital chlamydial infections, but also for herpes simplex virus (HSV) and human papillomavirus (HPV) infections, which are assuming increasing epidemiological importance in Europe. ${ }^{2}$ For such STIs, numbers of reported cases will reflect a complex mix of STI screening practices, partner notification practices, performance characteristics of diagnostic tests used, as well as coverage and representativeness of surveillance systems. ${ }^{45-47}$ Furthermore, high proportions of cases of chlamydial infection and viral STIs are seen in primary care settings, reflecting their distribution in the population as endemic infections not particularly strongly associated with high risk groups. ${ }^{44}$ Universal or sentinel laboratory reporting of such STIs, with denominator data, can to some extent circumvent problems of coverage and representativeness of clinical case reporting, particularly from primary healthcare settings, and are in place in a number of countries. However, the sensitivity of laboratory reporting for detecting the true number of infections occurring in the population still depends crucially on screening and partner notification practices. Prevalence assessment and monitoring systems are necessary to accurately monitor rates of infection with these STIs. ${ }^{48}$ Prevalence monitoring systems could be integrated into already existing sentinel case reporting systems, which include a sample of all sites where STIs are detected and treated, including primary care sites.

Finally, an upcoming challenge for STI surveillance is the development of vaccines for viral STI infections, particularly HPV, where clinical trials have shown high short term efficacy in the prevention of genital HPV infection and development of low grade cervical intraepithelial lesions. ${ }^{49}$ Vaccine development for HSV infection, while as yet less successful, is also under way. ${ }^{50}$ Here, prevalence monitoring will be necessary to assess infection rates and determine target populations for vaccination, as well as being an essential component of evaluation of the coverage and effectiveness of vaccination programmes.

\section{CONCLUSIONS}

The results of the present survey confirm that, despite heterogeneity in currently existing STI surveillance systems, similar priorities exist for improvements to systems in different countries, as well as similarly implemented novel responses. The aim of the ESSTI (European Surveillance of STIs) Network is to provide a forum where countries can learn from each other and transfer skills and experience, and to act as a stimulus for improvements to country systems where necessary, so enabling more meaningful data comparisons. Definition of standardised minimum datasets, and use of sentinel and enhanced surveillance systems to supplement universal case and/or laboratory reporting data where necessary, would substantially improve our understanding of STI epidemiology and of the factors driving STI transmission across Europe, as well as facilitating sharing of information and aiding in the design and implementation of effective public health responses.

\section{ACKNOWLEDGEMENTS}

Financial support for this study was provided by the European Commission (DG SANCO), Agreement No SI2.325878 (2001CVG4-018): ESSTI European Surveillance of Sexually Transmitted Infections. The authors thank Michel Alary for critical reading of the manuscript.

\section{CONTRIBUTORS}

CML was responsible for all aspects of study and questionnaire design, data analysis, and manuscript preparation; KAF contributed to study and questionnaire design, and to preparation of the manuscript; members of the ESSTI Collaborative Group completed the study questionnaire, provided additional information concerning STI surveillance systems, and contributed to preparation of the manuscript; members of the ESSTI Steering Group contributed to questionnaire design and piloting, and to preparation of the manuscript.

\section{ESSTI Network: members of ESSTI collaborative and steering groups}

Austria: Reinhild Strauss, BM for Social Security and Generations, Vienna, Austria; Angelika Stary, Outpatient Center for Diagnosis of Infectious Venerodermatological Diseases, Vienna. Belgium: Andre Sasse, Epidemiology Section, Scientific Institute of Public Health, Brussels; Marjan Van Esbroeck, Inst. voor Tropishe Geneeskunde, Antwerp. Denmark: Else Smith, Department of Epidemiology, Statens Serum Institut, Copenhagen; Steen Hoffmann*, Department of Epidemiology, Statens Serum Institut, Copenhagen. Finland: Matti Lehtinen, National Public Health Institute, Helsinki; Pentti Huovinen, Antimicrobial Research Laboratory, National Public Health Institute, Turku. France: Veronique Goulet; Francoise Hamers*, Institut de Veille Sanitaire; Dépt des maladies infectieuses, St Maurice; Patrice Sednaoui, Laboratoire de Bactériologie, Institut Fournier, Paris. Germany: Osamah Hamouda, Infektionsepidemiologie/AIDS-Zentrum, Robert Koch Institut, Berlin; Peter Kohl, Department of Dermatology and Venereology, Neukolln Academic Hospital, Free University of Berlin. Greece: Mina Psichogiou, Hellenic Center for Infectious Diseases Control, Department for Surveillance and Intervention, Athens; Eva Tzelepi, National Reference Center for N gonorrhoeae, Hellenic Pasteur Institute, Athens. Ireland: Mary Cronin, National Disease Surveillance Centre, Dublin. Italy: Barbara Suligoi*, Laboratory of Epidemiology and Biostatistics, Istituto Superiore di Sanità, Rome; Paola Stefanelli, Department of Infectious, Parasitic and Immuno-mediated Diseases, Istituto Superiore di Sanità, Rome. Netherlands: Marita van de Laar*, National Institute of Public Health and the Environment (RIVM), Department of Infectious Disease Epidemiology, Bilthoven; Joke Spaargaren, GG and GD Amsterdam, Public Health Laboratory, Amsterdam. Norway: Hans Blystad, Norwegian Institute of Public Health, Oslo; Jorgen Lassen, Norwegian Institute of Public Health, Oslo. Portugal: Jacinta Azevedo, Consulta de DST do Centro de Saude da Lapa, Lisbon; Maria Jose Borrego, Centro de Bacteriologia, Instituto Nacional de Saude Dr Ricardo Jorge, Lisbon. Spain: Jesús Castilla, Centro 
Nacional de Epidemiología, Instituto de Salud Carlos 1ll, Madrid; Julio Vazquez, Centro Nacional de Microbiologia, Madrid. Sweden: Torsten Berglund*, Swedish Institute for Infectious Disease Control, Solna; Johan Giesecke*, Swedish Institute for Infectious Disease Control, Solna; Hans Fredlund, Swedish Reference Laboratory for Pathogenic Neisseria, University Hospital, Örebro. UK: Mike Catchpole*, Health Protection Agency Communicable Disease Surveillance Centre, London; Hugh Young*, Scottish Neisseria gonorrhoeae Reference Laboratory (SNGRL), Laboratory Medicine (Microbiology), Edinburgh Royal Infirmary, Edinburgh; Chris Bartlett*, UCL Centre for Infectious Disease Epidemiology, Department of Primary Care and Population Sciences, London; Cathy Ison*, Department of Infectious Diseases and Microbiology, Imperial College School of Medicine, London; Jodi Cooper, Health Protection Agency Communicable Disease Surveillance Centre, London; Anne Scoular, Scottish Centre for infection and Environmental Health, Glasgow.

${ }^{*}$ Member of ESSTI Steering Group.

\section{Authors' affiliations}

C M Lowndes, K A Fenton, Department of HIV and Sexually Transmitted Infections, Health Protection Agency Communicable Disease Surveillance Centre, 61 Colindale Avenue, London NW9 5EQ, UK K A Fenton, Centre for Sexual Health and HIV Research, Department of Primary Care and Population Sciences and Department of Sexually Transmitted Diseases, Royal Free and University College Medical School, Mortimer Market Centre, off Capper Street, London WC1E 6AU, UK

\section{REFERENCES}

1 Nicoll A, Hamers FF. Are trends in HIV, gonorrhoea, and syphilis worsening in western Europe? BMJ 2002;324:1324-7.

2 Fenton KA, Lowndes CM, for the ESSTI (European Surveillance of STIs) Network. Recent trends in the epidemiology of sexually transmitted infections in the European Union. Sex Transm Infect 2004;80:255-63.

3 European Centre for the Epidemiological Monitoring of AIDS. HIV/AIDS surveillance in Europe. End-year report 2001. Sainte-Maurice: Institut de Veille Sanitaire, 2002:66.

4 Fenton K, Giesecke J, Hamers FF. Europe-wide surveillance for sexually transmitted infections: a timely and appropriate intervention. Euro Surveill $2001 ; 6: 69-70$.

5 CDC (Centers for Disease Control). Updated guidelines for evaluating public health surveillance systems; recommendations from the Guidelines Working Group. MMWR Recomm Rep 2001;50:1-35.

6 Kunkel A, Kock-Hansen GH, Smith E. Gonorrhoea 2001. EpiNews 2002:50 (Statens Serum Institut).

7 Statens Serum Institut. Syphilis 2000-2001. EpiNews 2002:26-33.

8 Greco D, Giuliani M, Suligoi B, et al. Sexually transmitted diseases in Italy: clinical returns versus statutory notifications. Genitourin Med 1990:66:383-6.

9 Hoffmann S. The laboratory surveillance system of Chlamydia trachomatis and Neisseria gonorrhoeae infections in Denmark. Euro Surveill 2001;6:86-90.

10 Hughes G, Paine T, Thomas D. Surveillance of sexually transmitted infections in England and Wales. Euro Surveill 2001;6:71-80.

11 Hiltunen-Back $E$, Haikala $\mathrm{O}$, Kautiainen $\mathrm{H}$, et al. A nationwide sentinel clinic survey of Chlamydia trachomatis infection in Finland. Sex Transm Dis $2001 ; 28: 252-8$.

12 Suligoi B, Giuliani M and the STD Surveillance Working Group. Sentinel surveillance of sexually transmitted diseases in Italy. Euro Surveill 1998;3:55-8

13 Dal Conte I, Lucchini A, Contuzzi E, et al. Sexually transmitted infections in Italy: an overview. Int J STD AIDS 2001;12:813-18.

14 Lisboa C, Azevedo J, Santo I, Grupo de Estudo e Investigação das Doenças Sexualmente Transmissíveis (GEIDST). [Vigilancia epidemiologica das IST. Experiencia de dois anos: 2000-2001], 2002. Oral presentation; $7^{\circ}$ Congresso Nacional de Dermatovenereologia; 17-19 May 2002; Coimbra, Portugal. Trabalhos da Sociedade Portuguesa de Dermatologia e Venereologia 2002;60:100-1.

15 Van Kersschaever G, Sasse A. The development of a sexual transmitted infections (STI) sentinel surveillance system in Belgium. Poster presentation: 14th Biennial Congress of the International Society for Sexually Transmitted Diseases Research (ISSTDR) Berlin, Germany, June 24-27, 2001. Sex Transm Infect 2001;12(suppl 2):89.

16 Massari V, Retel O, Flahault A. A recent increase in the incidence of male urethritis in France. Sex Transm Dis 2002;29:319-23

17 Goulet V, Sednaoui P, Massari V, et al. Confirmation de la recrudescence des gonococcies en France depuis 1998. Bulletin épidémiologigue hebdomadaire $2001 ; 14: 61-3$

18 Meyer L, Goulet V, Massari V, et al. Surveillance of sexually transmitted diseases in France: recent trends and incidence. Genitourin Med 1994;70:15-21.
19 Domegan L, Cronin M, Thornton L, et al. Enhanced surveillance of syphilis. Epi-Insight 2002;3:2-3.

20 Institute of Public Health (IPH), Unit of Epidemiology. Trends of syphilis cases reported by the sentinel lab network 2000-2001. IPH/EPI Reports No 2001008.

21 Department of Health (England). The national strategy for sexual health and HIV implementation action plan. London: DoH, 2002.

22 Van den Hoek JA, Mulder-Folkerts DK, Coutinho RA, et al. [Opportunistic screening for genital infections with Chlamydia trachomatis among the sexually active population of Amsterdam. I. Over $90 \%$ participation and almost 5\% prevalence]. Ned Tijdschr Geneeskd 1999;143:668-72.

23 Moller JK, Andersen B, Olesen F, et al. Reasons for Chlamydia trachomatis testing and the associated age-specific prevalences. Scand J Clin Lab Invest 2003;63:339-45

24 Arthur G, Lowndes CM, Blackham J, et al, and the European Surveillance of Sexually Transmitted Infections (ESSTI) Network. Divergent approaches to partner notification for sexually transmitted infections across the European Union. (Submitted for publication.)

25 Bingham JS. Services for sexually transmitted infections in Europe and central Asia. Sex Transm Infect 2002;78:320-1.

26 Moi H. Care of sexually transmitted infections in the Nordic countries. Int J STD AIDS 2001;12:819-23.

27 Petzoldt D, Jappe U, Hartmann M, et al. Sexually transmitted diseases in Germany. Int J STD AIDS 2002;13:246-53.

28 Coenen AJ, Berends R, van der Meijden WI. The organization of STI control in the Netherlands - an overview. Int J STD AIDS 2002;13:254-60

29 Dehne KL, Riedner G, Neckermann C, et al. A survey of STI policies and programmes in Europe: preliminary results. Sex Transm Infect 2002;78:380-4.

30 Desenclos JC, Bijkerk $\mathrm{H}$, Huisman J. Variations in national infectious diseases surveillance in Europe. Lancet 1993;341:1003-6.

31 Panchaud C, Singh S, Feivelson D, et al. Sexually transmitted diseases among adolescents in developed countries. Fam Plann Perspect 2000;32:24-32, 45.

32 Bell A, Ncube F, Hansell A, et al. An outbreak of hepatitis A among young men associated with having sex in public venues. Commun Dis Public Health 2001:4:163-70.

33 Bovee LP, Peerbooms PG, van den Hoek JA. [Shigellosis, a sexually transmitted disease in homosexual men]. Ned Tijdschr Geneeskd 2003; 147:2438-9.

34 Marcus U, Zucs P, Bremer V, et al. Cluster of shigellosis in men in Berlin in 2001. Eurosurveillance Weekly 2002:6 (15 August 2002).

35 Reintjes R, Bosman A, de Zwart O, et al. Outbreak of hepatitis A in Rotterdam associated with visits to 'darkrooms' in gay bars. Commun Dis Public Health 1999;2:43-6.

36 Stene-Johansen K, Jenum PA, Hoel T, et al. An outbreak of hepatitis A among homosexuals linked to a family outbreak. Epidemiol Infect 2002;129:113-7.

37 Gotz H, Nieuwenhuis R, Ossewaarde T, et al. Preliminary report of an outbreak of lymphogranuloma venereum in homosexual men in the Netherlands, with implications for other countries in western Europe. Eurosurveillance Weekly 2004:8, issue 4.

38 Nissinen A, Jarvinen $\mathrm{H}$, Liimatainen $\mathrm{O}$, et al. Antimicrobial resistance in Neisseria gonorrhoeae in Finland, 1976 to 1995. The Finnish Study Group For Antimicrobial Resistance. Sex Transm Dis 1997;24:576-81.

39 Tzelepi E, Avgerinou H, Kyriakis KP, et al. Antimicrobial susceptibility and types of Neisseria gonorrhoeae in Greece. Data for the 4-year period 19901993. Sex Transm Dis 1997;24:378-85.

40 Fenton KA, Ison C, Johnson AP, et al, GRASP collaboration. Ciprofloxacin resistance in Neisseria gonorrhoeae in England and Wales in 2002. Lancet 2003;361:1867-9.

41 Mavroidi A, Tzouvelekis LS, Kyriakis KP, et al. Multidrug-resistant strains of Neisseria gonorrhoeae in Greece. Antimicrob Agents Chemother $2001 ; 45: 2651-4$

42 Berglund $T$, Unemo M, Olcen $P$, et al. One year of Neisseria gonorrhoeae isolates in Sweden: the prevalence study of antibiotic susceptibility shows relation to the geographic area of exposure. Int J STD AIDS 2002;13:109-14.

43 Ferreira E, Louro D, Gomes JP, et al. High level tetracycline resistant Neisseria gonorrhoeae isolated in Portugal. Pathologie Biologie 1997;45:371-5.

44 Catchpole MA. The role of epidemiology and surveillance systems in the control of sexually transmitted diseases. Genitourin Med 1996:72:321-9.

45 Gotz H, Lindback J, Ripa T, et al. Is the increase in notifications of Chlamydia trachomatis infections in Sweden the result of changes in prevalence, sampling frequency or diagnostic methods? Scand J Infect Dis 2002;34:28-34.

46 Mardh PA. Limitations of current surveillance programs for sexually transmitted infections and allied conditions affecting reproductive health care. Eur J Contracept Reprod Health Care 1998;3:147-54.

47 Mardh PA. Improvement of surveillance programs for sexually transmitted infections and related conditions. Eur J Contracept Reprod Health Care 1998;3:136-46.

48 Simms I, Hurtig AK, Rogers PA, et al. Surveillance of sexually transmitted infections in primary care. Sex Transm Infect 2003;79:174-6.

49 Koutsky LA, Ault KA, Wheeler CM, et al. A controlled trial of a human papillomavirus type 16 vaccine. N Engl J Med 2002;347:1645-51.

50 Stanberry LR, Spruance SL, Cunningham AL, et al. Glycoprotein-D-adjuvant vaccine to prevent genital herpes. N Engl J Med 2002;347:1652-61. 